\title{
Topical ophthalmic $\beta$ blockers may cause release of histamine through cytotoxic effects on inflammatory cells
}

\author{
Luc M van Beek, Marcel Mulder, Nicolaas J van Haeringen, Aize Kijlstra
}

\begin{abstract}
Aim-To evaluate the effects of $\beta$ blockers used in ophthalmology on the release of histamine from mixed cell preparations containing human leucocytes and basophils.

Methods-A mixed leucocyte and basophil preparation was obtained from venous blood of healthy non-atopic volunteers. Cell preparations were then incubated with betaxolol, metipranolol, timolol, or carteolol. After incubation for 1 hour the histamine content of the supernatant was analysed by automated fluorometric analysis. Cell viability was tested by measuring lactate dehydrogenase (LDH) concentrations.
\end{abstract}

Results-Betaxolol and metipranolol in concentrations between $10^{-2} \mathrm{M}$ and $10^{-3} \mathrm{M}$ liberated histamine from human blood cells in a dose dependent manner. Carteolol and timolol had no effect on histamine at these concentrations. At the same concentrations LDH was also detected in the supernatants of cell suspensions incubated with metipranolol or betaxolol.

Conclusions-Betaxolol and metipranolol induce substantial histamine release from human leucocytes, probably as a result of their cytotoxic effect.

(Br f Ophthalmol 2000;84:1004-1007)

Topical $\beta$ blockers are widely used to lower intraocular pressure in glaucoma and ocular hypertension. Topical $\beta$ blockers can cause serious systemic side effects ${ }^{1}$; ocular side effects including stinging or burning upon instillation, foreign body sensation, dry eyes, periorbital dermatitis, conjunctivitis, keratitis, and uveitis have also been described. ${ }^{2}$

Mast cells, which are abundant in the conjunctiva, ${ }^{3}$ play a pivotal role in type I hypersensitivity. Mast cells release histamine and other preformed mediators upon stimulation. Histamine causes itching, hyperaemia, and increases vascular permeability. Earlier reports indicate that histamine is released from isolated rat mast cells after incubation with certain $\beta$ blockers. ${ }^{4}$ This suggests that some $\beta$ blockers may have pseudoallergic properties which may account for some of the ocular side effects of these drugs.

Release of histamine from mast cells (degranulation) is the result of either IgE dependent or $\operatorname{IgE}$ independent mechanisms. $\operatorname{IgE}$ is bound to high affinity IgE receptors $(\mathrm{Fc} \gamma \mathrm{RI})$ on the membrane of mast cells and basophils. Cross linking of these $\operatorname{IgE}$ antibodies by a diva- lent antigen (allergen) results, via a molecular cascade, in an increase in the intracellular calcium concentration. This in turn leads to release of histamine and other preformed mediators from the granules of the mast cell. Cross linking of the $\operatorname{IgE}$ antibodies also activates the enzyme adenyl cyclase which promotes the synthesis of cyclic adenosine monophosphate (cAMP) from ATP. Cyclic AMP inhibits degranulation, thus forming a negative feedback loop. ${ }^{5}$

Mast cells and basophils express $\beta$ receptors at their surface; these receptors are also coupled to adenyl cyclase. ${ }^{6}$ Activation of $\beta$ receptors increases the intracellular cAMP concentration which then acts as a second messenger. Blocking the $\beta$ receptors may thus disturb the negative feedback loop, making the mast cells more susceptible to degranulation. There have been several reports of a worsening or recurrence of atopic or anaphylactic reactions after starting treatment with systemic $\beta$ blockers.?

Betaxolol, carteolol, metipranolol, and timolol are $\beta$ blocking agents currently used for the treatment of glaucoma. We investigated whether these compounds could induce histamine release. As a model we used human basophils which have similar histamine releasing properties to mast cells. ${ }^{8}$

\section{Materials and methods}

ISOLATION OF LEUCOCYTES

Blood samples from healthy volunteers were collected in citrate tubes and suspended in an ice cold hypotonic ammonium chloride buffer, causing lysis of erythrocytes. The leucocytes were then washed twice with ice cold HEPES buffer containing $132 \mathrm{mM} \mathrm{NaCl}, 6 \mathrm{mM} \mathrm{KCl}$, $1 \mathrm{mM} \quad \mathrm{CaCl}_{2}, \quad 1 \mathrm{mM} \quad \mathrm{MgSO}_{4}, 1.2 \mathrm{mM}$ $\mathrm{K}_{2} \mathrm{HPO}_{4}, 20 \mathrm{mM} \mathrm{N}$-2-hydroxyethylpiperazine$\mathrm{N}-2$-ethanesulphonic acid (Sigma Chemical Co, St Louis, MO, USA), $5.5 \mathrm{mM}$ glucose, and $0.5 \%(\mathrm{w} / \mathrm{v})$ human serum albumin, $\mathrm{pH}$ 7.4, osmolality 280-300 mOsm/l. After washing the leucocytes were suspended in HEPES buffer and incubated with various $\beta$ blockers.

The volunteers $(n=14)$ were free of atopic disease and were not taking any medication. Several different concentrations (usually three) of $\beta$ blockers were tested in duplicate on each blood sample. All volunteers gave their informed consent and the study conformed to the Universal Declaration of Human Rights and to the European Convention for the Protection of Human Rights and Fundamental Freedoms.

The number of leucocytes per aliquot ranged from $46.2 \times 10^{5}$ to $73.5 \times 10^{5}$. Approxi- 
mately $0.5 \%$ of leucocytes are basophils, ${ }^{9}{ }^{10}$ giving a number of approximately $23.1-36.7 \times$ $10^{3}$ basophils per aliquot. The leucocytes were divided into aliquots of $250 \mu \mathrm{l}$ to which $50 \mu \mathrm{l}$ of a $\beta$ blocker solution or phosphate buffered saline (control) was added (final volume $300 \mu \mathrm{l})$. The aliquots were then incubated for 1 hour at $37^{\circ} \mathrm{C}$. After incubation the leucocytes were centrifuged $(500 \mathrm{~g})$ at room temperature and the supernatant was analysed for lactate dehydrogenase (LDH) or histamine.

In some experiments the viability of the cells was tested using trypan blue staining. Also, in some experiments cell pellets were resuspended after incubation and the cells were counted again. For the staining procedure cells were diluted $1: 10$ in trypan blue solution $0.3 \%$ in phosphate buffered saline. Cells were counted using phase contrast microscopy (Leica 090-131.001).

HISTAMINE ASSAY

Perchloric acid to a final concentration of $2 \%$ was added to $250 \mu \mathrm{l}$ of the supernatant of incubated cell suspensions. The supernatants were then stored at $4^{\circ} \mathrm{C}$ until analysis (maximum 60 days). The histamine content was determined at the department of allergy at the central laboratory of blood transfusion (Amsterdam) by an automated spectrofluorometric o-phthalaldehyde assay. ${ }^{112}$ Briefly, this method consists of extracting histamine and coupling it to o-phthalaldehyde. The fluorescence of this complex is then measured by a spectrofluorometer using an excitation wavelength of $355 \mathrm{~nm}$ and an emission wavelength of $450 \mathrm{~nm}$. It is assumed that the measured fluorescence was proportional to the concentration of histamine.

Because the number of basophils and the amount of histamine vary between individuals, the histamine content was expressed as a percentage of the total histamine. Total histamine was obtained by adding perchloric acid (final concentration $2 \mathrm{mg} / \mathrm{ml}$ ) to one aliquot of leucocytes in each blood sample to cause lysis of the cells. This aliquot was then centrifuged and histamine was determined using the method described above. Percentages were corrected for spontaneous release which was defined as the histamine content of the supernatant of the control sample. The results were discarded if spontaneous release exceeded $15 \%$.

LACTATE DEHYDROGENASE (LDH) ASSAY

Directly after the incubation experiments the supernatant of incubated cell suspensions was analysed for LDH content. Supernatant $(5 \mu \mathrm{l})$ was mixed with $200 \mu \mathrm{l}$ substrate buffer in a 96 well flat bottom plate. The substrate buffer contained $3.8 \mathrm{mM} \mathrm{Na}_{2} \mathrm{PO}_{4}, 1.9 \mathrm{mM} \mathrm{KH}_{2} \mathrm{PO}_{4}$, $7.9 \mu \mathrm{g} / \mathrm{ml}$ pyruvic acid, and $15.9 \mu \mathrm{g} / \mathrm{ml}$ $\mathrm{NADH}, \mathrm{pH}$ 7.0. In this mixture $\mathrm{LDH}$ converts NADH to NAD at a rate determined by the amount of LDH present. ${ }^{13}$ Experiments were performed at room temperature. Each 96 well plate contained total, control, and tested $\beta$ blocker concentrations in duplicate.
Table 1 Histamine release from human leucocyte suspensions of healthy volunteers $(n=14)$ after 1 hour incubation with $\beta$ blockers $(0.01 \mathrm{M})$ used in treatment of glaucoma

\begin{tabular}{ll}
\hline$\beta$ blocker & Mean (SD) histamine release (\%) \\
\hline Betaxolol & $88.5(5.1)$ \\
Metipranolol & $78.8(6.9)$ \\
Timolol & $18.5(11.5)$ \\
Carteolol & $0(0)$ \\
\hline
\end{tabular}

Directly after starting the reaction, extinction was measured with a photospectrometer (iEMS Reader MF, Labsystems, Helsinki, Finland) at $340 \mathrm{~nm}$ every minute for 10 minutes to follow clearance of $\mathrm{NADH}$ from the reaction mixture. It was assumed that the change in the level of absorption was proportional to the amount of LDH activity in the samples. The amount of $\mathrm{LDH}$ was expressed as a percentage of the total, corrected for spontaneous release which never exceeded $10 \%$. Total LDH was obtained by sonification of one aliquot of leucocytes. Sonification took place with a $30 \mathrm{kHz}$ microprobe (Soniprep 150, MSE, Loughborough, UK) for 15 seconds and was repeated seven times during which the suspension was kept on ice. After sonification the suspension was centrifuged at $500 \mathrm{~g}$ for 15 minutes. Spontaneous release was determined by measuring the LDH content of the control supernatant.

AGENTS

Betaxolol, carteolol, metipranolol, and timolol were provided by Tramedico BV, Weesp, Netherlands. They were dissolved in phosphate buffered saline without preservatives.

\section{Results}

Initially we tested four $\beta$ blockers (carteolol, betaxolol, metipranolol, and timolol) for their ability to release histamine from isolated leucocytes. These $\beta$ blockers are currently in use for the treatment of glaucoma. After incubation for 1 hour at a concentration of $0.01 \mathrm{M}$, betaxolol and metipranolol released $79 \%$ and $88 \%$, respectively, of the total histamine content from the basophils. At the same concentration timolol released only $18 \%$ of the histamine and carteolol did not release any (Table 1).

We then constructed dose-response curves for betaxolol, metipranolol, and timolol which are shown in Figure 1. Metipranolol and betaxolol in concentrations between $10^{-2} \mathrm{M}$ and $10^{-3} \mathrm{M}$ liberated histamine in a dose dependent manner. Timolol liberated significantly less histamine than either of the other $\beta$ blockers at the highest concentration $\left(10^{-2} \mathrm{M}\right)$.

To explain these results we hypothesised that the histamine releasing effect could be either specific (that is, mediated by the $\beta$ receptor), non-specific, or cytotoxic. Trypan blue cell counts performed both before and after incubation indicated that cell numbers decreased during incubation with $\beta$ blockers (data not shown). To quantitate this effect, $\mathrm{LDH}$ was measured in the supernatant after incubation. Results of these experiments are shown in Fig 2. Again, timolol released signifi- 


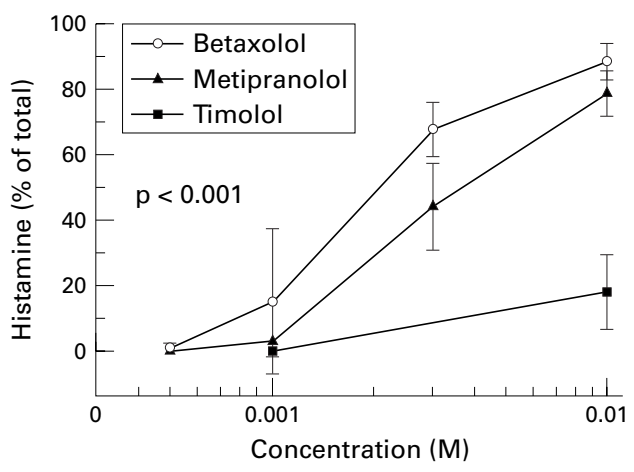

Figure 1 Histamine release from human leucocyte suspensions after incubation for 1 hour at $37^{\circ} \mathrm{C}$ with various $\beta$ blockers. Release is expressed as mean percentage with standard deviation of total histamine $(n=14)$. $p<0.001$ for difference between betaxolol and timolol and between metipranolol and timolol at $10^{-2} \mathrm{M}$ (Student's $t$ test).

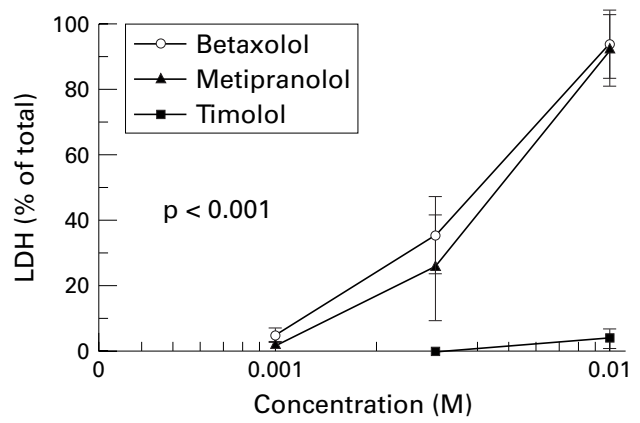

Figure 2 Lactate dehydrogenase ( $L D H)$ expressed as percentage of total LDH in supernatant of leucocyte suspensions after incubation for 1 hour at $37^{\circ} \mathrm{C}$ with various $\beta$ blockers. Mean values with standard deviations are shown $(n=14) . p<0.001$ for difference between betaxolol and timolol and between metipranolol and timolol at $10^{-2} \mathrm{M}$ (Student's $t$ test).

cantly less LDH than either betaxolol or metipranolol.

\section{Discussion}

This study shows that histamine is liberated from human basophils by betaxolol and metipranolol and, to a significantly lesser extent, by timolol. The fact that we detected $\mathrm{LDH}$ in the supernatant indicated that the $\beta$ blocker concentrations we used were cytotoxic to leucocytes. This cytotoxic effect may also explain the histamine liberation because we do not consider that high concentrations of $\beta$ blockers are less toxic to basophils than to other leucocytes. Also, in previous studies other authors have used $\mathrm{LDH}$ levels to determine the cytotoxic effects on basophils in similar test conditions. ${ }^{14}$

Betaxolol and timolol formulations are commercially available in $0.1 \%, 0.25 \%$, and $0.5 \%$ concentrations and metipranolol formulations are commercially available in $0.1 \%, 0.3 \%$, and $0.6 \%$ which equals approximately $2.5 \times 10^{-3}$ to $2 \times 10^{-2} \mathrm{M}$. The cytotoxicity found in these experiments therefore occurs at concentrations that are used in commercial formulations. However, it should be noted that, upon instillation of an eye drop, the concentration decreases by dilution with tear fluid and by binding of the $\beta$ blocker to proteins in the tear
Table 2 Lipid solubility of the tested $\beta$ blockers ${ }^{23}$

\begin{tabular}{ll}
\hline$\beta$ blocker & Lipid solubility $(\log P)$ \\
\hline Betaxolol & 2.81 \\
Metipranolol & 2.28 \\
Timolol & 1.16 \\
Carteolol & 0.82 \\
\hline
\end{tabular}

fluid. Also, the contact time of the drug will be shorter than the 1 hour used in our experiments.

Nosal et $a l^{15}$ investigated histamine release from isolated rat mast cells after incubation with metipranolol and several other $\beta$ blockers. Metipranolol in a concentration of $10^{-3} \mathrm{M}$ resulted in a $5 \%$ histamine release which is in accordance with our results. They did not test higher concentrations nor did they test for cell viability after incubation. They further found that a $\beta$ blocker with a higher lipophilicity (exaprolol) induced histamine release at $10^{-3} \mathrm{M}$ which they concluded was a non-specific effect caused by perturbation of the cell membrane.

Takahashi ${ }^{16}$ tested the cytotoxicity of timolol on conjunctival cell cultures and found that timolol $0.5 \%\left(10^{-2} \mathrm{M}\right)$ did not posses any cytotoxicity. Similarly, we did not find significant cytotoxicity with timolol $\left(10^{-2} \mathrm{M}\right)$ on leucocytes.

In our experiments metipranolol and betaxolol had a significantly higher cytotoxicity than timolol. Timolol has a considerably lower lipid solubility than betaxolol and metipranolol (Table 2).${ }^{17}$ We feel that, because of their higher lipid solubility, betaxolol and metipranolol disturb the cell membrane integrity and that this accounts for their higher cytotoxicity. However, it should be kept in mind that eye drops need to have a certain lipid solubility to penetrate the cornea. ${ }^{18}$ In a single drop study timolol was found to reduce exercise tachycardia in contrast to metipranolol. The authors explained this by the higher lipid solubility of metipranolol permitting rapid cornea penetration and leaving less metipranolol available for systemic absorption. ${ }^{19}$

In general, patients find timolol eye drops more comfortable than metipranolol or betaxolol eye drops. ${ }^{20-23}$ Because the vehicles of the three eye drops are comparable, the low cytotoxic effect of timolol may be partly responsible for its higher degree of comfort.

This research was supported by a grant of Dr Gerhard Mann GmbH, Germany, and Tramedico BV, Netherlands.

1 Zimmerman TJ, Baumann JD, Hetherington J Jr. Side effects of timolol. Surv Ophthalmol 1983;28(Suppl):24351

2 Akingbehin T, Villada JR. Metipranolol-associated granulomatous anterior uveitis. Br f Ophthalmol 1991;75:519-23.

3 Allansmith MR, Korb DR, Greiner JV, et al. Giant papillary conjunctivitis in contact lens wearers. Am $\mathcal{f}$ Ophthalmol 1977;83:697-708.

4 Nosal R, Ondrias K, Pecivova J, et al. Histamine liberation and membrane fluidisation of mast cells exposed to the beta-adrenoceptor blocking drug propranolol. Agents Actions 1988;23:143-5.

5 Lichtenstein LM, DeBernardo R. The immediate allergic response: in vitro action of cyclic AMP-active and other drugs on the two stages of histamine release. 7 Immunol 1971;107:1131-6.

6 Perper RJ, Sanda M, Lichtenstein LM. The relationship of in vitro and in vivo allergic histamine release: inhibition in primates by cAMP active agents. Int Arch Allergy Appl primates by cAMP active

7 Kaplan AP, Anderson JA, Valentine MD, et al. Betaadrenergic blockers, immunotherapy, and skin testing. 
American Academy of Allergy and Immunology. F Allergy Clin Immunol 1989;84:129-30.

8 Council on Scientific Affairs. In vitro testing for allergy. Report II of the Allergy Panel. fAMA 1987;258:1639-43.

9 Fawcett DW. Bloom and Fawcett, a textbook of histology. 11th ed. Philadelphia: WB Saunders, 1986.

10 Alberts B, Bray D, Lewis J, et al. Molecular biology of the cell. 2nd ed. New York and London: Garland Publishing Inc, 1989.

11 Siraganian RP. An automated continuous-flow system for the extraction and fluorometric analysis of histamine. Anal Biochem 1974;57:383-94.

12 Witteman AM, Mulder M, Aalberse RC, et al. Bronchial allergen challenge in subjects with low levels of allergic sensitization to indoor allergens. Allergy 1998;54:366-74.

13 Decker T, Lohmann-Matthes ML. A quick and simple method for the quantitation of lactate dehydrogenase release in measurements of cellular cytotoxicity and tumor necrosis factor (TNF) activity. F Immunol Methods 1988; 115:61-9.

14 Miadonna A, Tedeschi A, Leggieri E, et al. Effect of nitrendipine on histamine release from human basophil leucocytes. Allergy 1987;42:298-304.

15 Nosal R, Pecivova J, Drabikova K. On the interaction of beta-adrenoceptor-blocking drugs with isolated mast cells. Agents Actions 1985;16:478-84.
16 Takahashi N. A new method evaluating quantitative time-dependent cytotoxicity of ophthalmic solutions in cell culture. Beta-adrenergic blocking agents. Graefes Arch Clin Exp Ophthalmol 1983;220:264-7.

17 Cruickshank JM, Prichard BNC. Beta-blockers in clinical practice. 2nd ed. London: Churchill Livingstone, 1994.

18 Huang HS, Schoenwald RD, Lach JL. Corneal penetration behavior of beta-blocking agents. II: Assessment of barrier contributions. F Pharm Sci 1983;72:1272-9.

19 Bacon PJ, Brazier DJ, Smith R, et al. Cardiovascular responses to metipranolol and timolol eyedrops in healthy volunteers. Br f Clin Pharmacol 1989;27:1-5.

20 Kendall K, Mundorf T, Nardin G, et al. Tolerability of timolol and betaxolol in patients with chronic open-angle glaucoma. Clin Ther 1987;9:651-5.

21 Hickey-Dwyer $M$, Campbell SH, Harding S. Doubledmasked three-period crossover investigation of metipranolol in control of raised intraocular pressure. $f$ Ocul Pharmacol 1991;7:277-83.

22 Zimmerman TJ. Topical ophthalmic beta-blockers: a comparative review. F Ocul Pharmacol 1993;9:37384.

23 Sorensen SJ, Abel SR. Comparison of the ocular betablockers. Ann Pharmacother 1996;30:43-54. 